\title{
Reflective Interiors: The Pepsi Pavilion and the Tower of the Sun
}

\author{
Kate Linzey
}

Japan's recovery from the destruction of World War Two resulted in swift and radical transformations in society and its built environment. Osaka Expo '70, like the Olympic Games which preceded it in 1964, was an event designed to demonstrate the strength of the emerging post-war economy, and the resilience of the Japanese people (Urushima 2007:394). The Expo theme "Harmony and Progress" was developed to integrate the national identity of traditional Japan (harmony) with new technologies, something viewed as Western and destructive (progress). While the theme was initially proposed by an independent "theme committee", Kenzo Tange and Nishiyama Uzô, who led the compelling elaboration of this vision by the "planological committee", enlarged their influence to the extent, as Pieter van Wesemael notes, that the architects became responsible for both theme and design, a first in the history of world exhibitions (2001: 570).

This essay will compare two interior spaces built in this context. They are, firstly, the Tower of the Sun by Tarô Okamoto, and secondly, the Pepsi Pavilion, by Experiments in Art and Technology (E.A.T.). While it is common for nationalised projects to explore how design can produce identity, Osaka Expo '70 presents an unusual instance where that identity was defined as unsettled, divided and pointedly anxiety-producing. Both works utilised ideas from psychoanalysis with the intention of soothing this anxiety. Where the first, though, relied on principles of surrealism, presenting familiar objects in strange and uncanny ways, the latter aimed to modify the very act of communication, transforming how things are recognised in relation to the self.

Isometric view of the Expo Osaka 70 site showing the location of Tarô Okamoto's Tower of the Sun on the Festival Plaza, and E.A.T.'s Pepsi Pavilion (all drawings by the author).

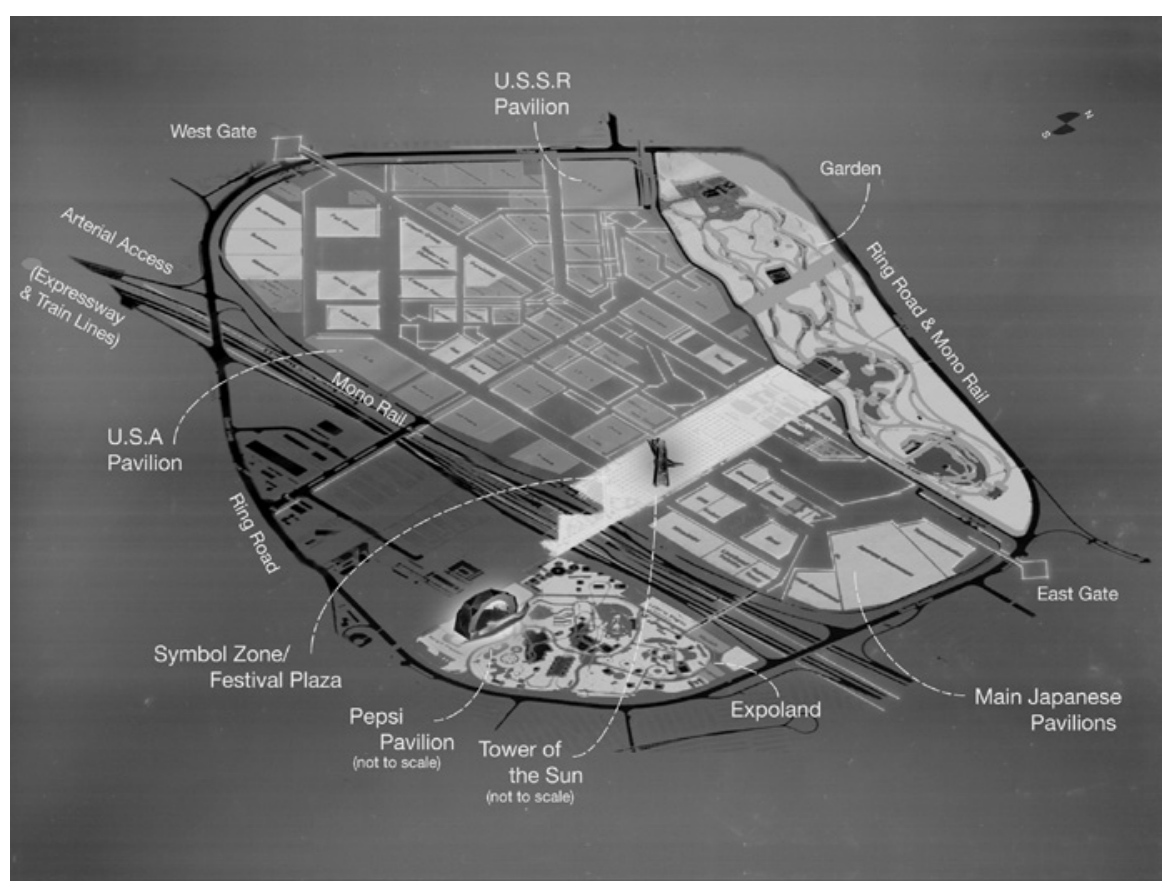




\section{Osaka Expo '70: Progress and Harmony}

In his historical survey of world exhibitions from 1798 onwards, van Wesemael presents Osaka as the culmination of an evolving world exhibition model. His survey has an architectural focus, exploring how architecture was used to frame each exhibition as, in his words, "a secluded universe" of fantasy and technology, entertainment and education (2001: 17). Van Wesemael tracks the transformation of the eighteenth-century pedagogical model, based on the panoramic display of global culture and didactic demonstrations of technology, through to Osaka's more nebulous pedagogy of engagement and self-realisation through play. Rather than merely educate the populace, the intention at Osaka was to "adjust ... the self-image of the Japanese with regard to themselves, their society and the future” (2001: 566).

Uzô and Tange's site planning of Expo Osaka '70 sought to demonstrate an ideal circulation infrastructure for Japan's growing urban centres. Ordered by a clear hierarchy of transportation methods, the Expo site was divided into four lobes, rather like a heart. According to van Wesemael, the architects sought to avoid any narrative or thematic structure in the distribution of pavilions (the placing of the U.S.S.R. and U.S.A. pavilions at diametrically opposite points on the site might be seen as an exception). By renouncing narrative or thematic devices to mediate between exhibitors and visitors, the design of the Expo site became, at least in theory, an architecture without qualities. Designers of individual pavilions were given maximum design flexibility and autonomy. This flexibility, Angus Lockyer (2007) argues, can be linked to the Expo architects' concern, not for what was represented, but for the spectacle of circulating signs. "Progress and harmony" was to be achieved, Lockyer implies, due to an architecture which only appeared through its ability to "account for contingency", that is, imperceptibly to incorporate and dissipate any disturbance (2007: 586).

This principle of contingent architecture was further developed by Arata Isozaki in his design of the "Festival Plaza" within the "Symbol Zone". Lockyer and Andrea Urushima (2007) attribute the concept of a central elevated area, or "Symbol Zone”, to Uzô's early planning influence. It provided a gathering axis for transportation and, by incorporating the "Festival Plaza" for live performances, could provide a space "where the vibrant and charged energy of the people [could be] discharged" (Uzô cited in van Wesemael 2001: 819, n49). As Urushima explains, Uzô’s concept for the Plaza had no precedent in Japanese cities or towns, but was created as a synthesis of Shinto Matsuri festival tradition with Uzô's experiences of Italian piazze. Tange delegated the task of interpreting Uzô's "Festival Plaza" to Isozaki who proposed a mega-structure canopy, which would permit the "plugging-in" of high-tech, multi-media and multi-sensory entertainment. Ordered by the grid of the space frame canopy, which was supported by piers expressed as circulation stairs, Isozaki's design was an architecture of coordinated systems. Van Wesemael has described it as "imageless" (2001: 598), Lockyer as "a system of interchangeable parts” (2007: 583), and Kisho Kurokawa as something like a flight simulator on which people train to occupy the technological future (Van Wesemael 2001: 594).

\section{Tower of the Sun: an opaque interiority or bombastic kitsch}

Years later, Isozaki described the Festival Plaza concept as "totally uncool” (2006: 71). He felt that the Osaka Expo '70's "battle for modernity" was lost on the pla$\mathrm{za}$ - primarily due to the inclusion of the work of senior artist, Okamoto (Isozaki 2006: 56). From an older generation, and imbued with a very different modernist sensibility, Okamoto responded to Uzô's invocation of the Matsuri festival tradition by producing designs referencing monstrous folk imagery. These, he hoped, 
Isometric section of the Tower of the Sun, drawn from a section of the tower published in Pieter van Wesemael (2001). would "shock visitors out of the complacency and anomie of everyday life" into celebratory festival (Lockyer 2007: 579). Most significant of these designs was Taiyo no To (Tower of the Sun), located centrally in the Festival Plaza. Described by Isozaki as "a giant phallus", as anti-modern and "bombastic kitsch", this tower is the only structure remaining on the Expo site today. Its persistence, along with the Festival Plaza as an urban form, has led Isozaki to complain that "the gaze searching for Japan-ness ... [discovers] itself most dramatically in the realm of bad taste" (2006: 72).

In photographs, the smoothly plastered, anthropomorphic mass of the Tower is an ambiguous monster overseeing activities on the Festival Plaza. Apparently monolithic, the Tower contrasts forcefully with the "imageless' aesthetic" (van Wesemael 2006: 598) of Isozaki's megastructure. Its sculpting is bulbous: a fat belly trunk rises up from the crisp flatness of the plaza, and conical arms, like branches, stretch out on either side of a face carved in a roundel mask. The Tower protrudes upward through a clean hole in the Plaza canopy. Above the canopy, the Tower is crowned by another face-like mask, but this one, geometrically abstract, gleams with a brassy metal surface like an ornamental antenna dish.

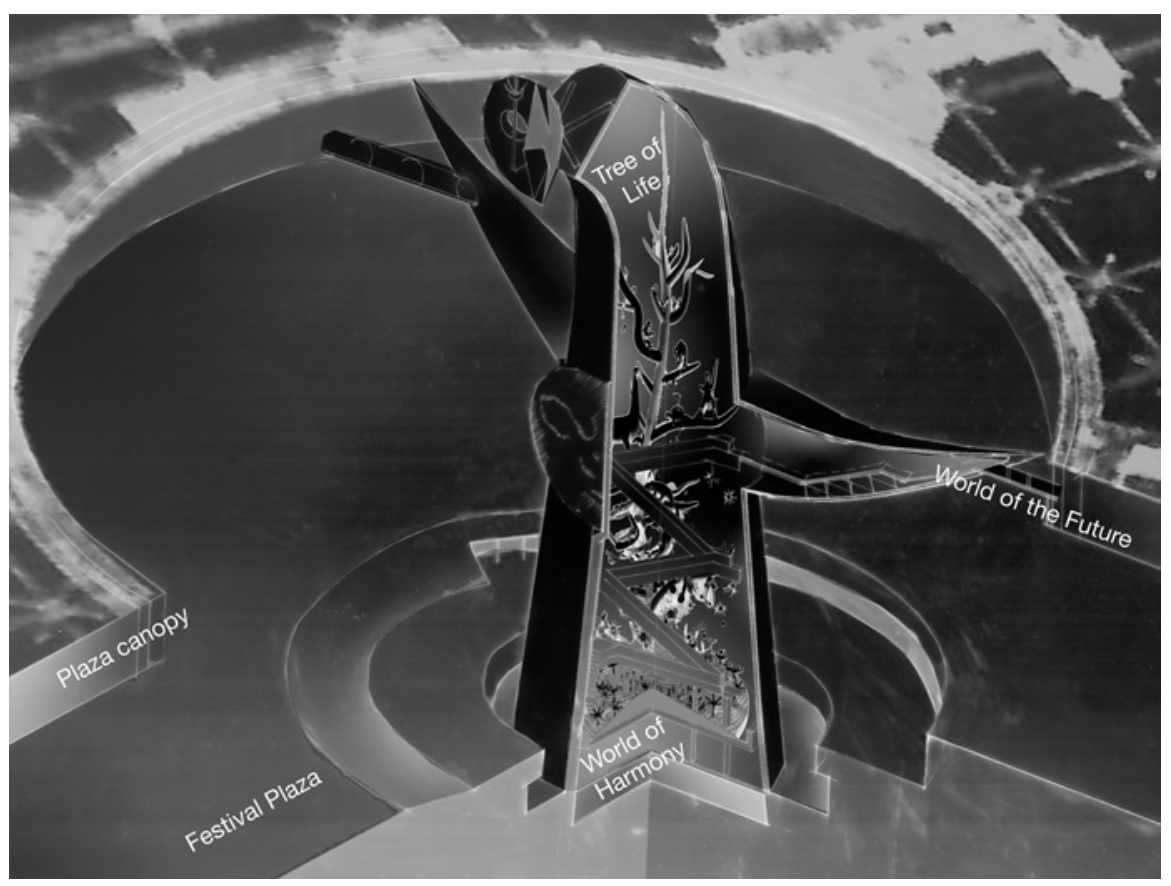

We think of the Tower of the Sun as a closed monolithic form but, during the Expo, it provided a sequence of interior spaces for an exhibition curated by Okamoto. Visitors entered at the plaza level, and then descended to an exhibit called the "World of Harmony": a display of scale models, archaeological specimens and re-constructions of prehistoric sites (Van Wesmael 2006: 598). Travelling on escalators, visitors entered the Tower itself and climbed past Okamoto's "Tree of Life" sculpture: a fantastically illuminated, caricatured tree with sinuous branches in a range of bright colours. At the base of this tree were flowers and models of single cell organisms. Higher up, dinosaurs perched precariously, too big for their branches, while primates and early humans appear to play at the top. Gantries led visitors along the arms of the Tower where, stepping out of the dimness, visitors would then arrive in the clear light of the glazed truss space of the roof, into the "World of the Future". Here they would discover images and models of "progress": satellites, diagrams of the brain, and Metabolist house-capsules (Van Wesemael 2006: 598; Lockyer 2007: 
578-580). Van Wesemael suggests the image of the Tower was of a Japanese culture with its "feet in tradition and its arms in the future" (2006: 598). For Isozaki, however, Okamoto's style could only express primitive superstition.

In 1955, Okamoto set out a thesis of culture and tradition in an essay on Jômon ceramics. Initiating a rhetorical structure that persists to this day, Okamoto favourably compared the "complex and manifest boldness verging on ugliness" of Jômon culture to the traditional "quiet and balanced ... tranquility" of the Yayoi style, which had conventionally defined Japan-ness (2009: 51, 54). Okamoto's argument self-consciously referenced European Surrealism and Gestalt psychology. He suggested that, by framing Japanese tradition in the culture of the hunter-gatherer Jômon rather than the agrarian Yayoi, a stronger contemporary culture would emerge:

The deceptive and feeble, flat emotionalism and formalism of the longstanding "Japanese" tradition has no connection with reality. Henceforth, artists will, by means of wisdom grounded in a primal vitality, open up that blind alley and grasp the true reality of the world. (Okamoto 2009: 59)

Okamoto's desire for "primal vitality" may be traced back to Wilhelm Worringer's 1907 proposition, in Abstraktion und Einfühlung (Abstraction and Empathy, 1953), which associated abstraction with the "immense spiritual dread of space" (1953: 15). ${ }^{1}$ The Tower and its exhibitions did not present an image of well-founded progressivism or confident naturalism. Rather, it was abstract, even cartoonish and deprecating. While the models presented DNA, dinosaurs and digital technologies, they also held them at a distance, as symbols of change and alienation. Okamoto's Tower provided a paradoxically uncanny and comforting distortion of the reality that "progress" would bring. Lockyer comments that the Tower became the most iconic remaining trace of the Expo on site even though its style was already out of date in 1970 (2007: 581). ${ }^{2}$ The Pepsi Pavilion, by contrast, which was absolutely new, is barely remembered in popular culture.

\section{Transparent interiority: the Pepsi Pavilion}

Collectively authored by the Experiments in Art and Technology (E.A.T.), but led by Robert Whitman, Robert Breer, Billy Klüver, David Tudor and Frosty Myers, the Pavilion aimed to bring artists and their work into a synthesis with new technologies and engineers. The aspiration was to humanise technologies through art providing the means through which individuals might acclimatise to the coming technological world. In similar terms, Randall Packer has described how the Pavilion presented visitors with "mind-altering 'realities' in [a] transformative 'theatre of the future"” (Packer 2004: 252). For Klüver, the Pavilion was art becoming "laboratory environment" (1972: preface), where the role of the visitor would be that of participant and performer. Underpinning this new role for art was a shift in the definition of the work: from an object to be read or viewed to a system or environment to be engaged in. From an art historical perspective, Barbara Rose describes this shift as a breaking down of art historical boundaries and a rejection of the concept of "aesthetic distance" (Rose 1972: 61).

Since the 1893 World's Columbian Exhibition in Chicago, World Exhibitions had been accompanied by a concession zone, or theme park, outside of the Exhibition grounds. ${ }^{3}$ At Expo Osaka '70 the concession zone was called Expoland. Located in this zone, the Pepsi Pavilion took on an ambiguous commercial/fine art status, appearing as both a branding exercise and an avant-garde joy ride. E.A.T. organisers
1 Referencing many styles from the primitive origins of art through to advanced 'Oriental' cultures (which included Japan), Worringer suggested that abstraction was a reaction that expressed dissatisfaction with the world, in contrast to the "happy ... confidence" (1953:15) of naturalism. Early twentieth-century movements like Surrealism drew on Worringer's argument to explain abstract art as a response to alienation from new technology, urbanism and global war. Okamoto's engagement with Surrealism during his time in Europe in the 1930s was reflected in the references to traditional Shinto Matsuri festival figurines in the Towe of the Sun. By adopting an abstract style, Okamoto responded to a fear, or at least awe, that visitors held of past, present and future, and to an anxiety concerning their place within the progress of history.

2 Current interest in the work of Okamoto has also led to a scaled reconstruction of the Tree of Life for exhibition in 201 (Taro Okamoto Museum), which suggests Okamoto's work is of more value to contemporary Japanese, the very subjects of Osaka Expo '70, than Lockyer or Isozaki are willing to admit.

3 An exception to this tradition had been the New York World Fair of 1965. 
Isometric section through the Pavilion drawn from images published in Klüver (1971) were concerned by these commercial implications, and resolved in early discussions that the best way to avoid producing a branded image was to make the structure disappear (Pearce 1972: 256). The final solution was to shroud the faceted white structure in fog, a similar technique to that which Diller and Scofidio would apply in their 2002 Blur Building. Visitors entered the Pavilion via a tunnel which descended approximately two metres to a subterranean Clam Room. So-called because of its circular shape and an enclosing curvature in the roof and floor, this grotto-like space was darkened for a laser display. The interior's size, depth underground, and exact limits, were intentionally obscured. Travelling to the far side of the room, and taking another tunnel-stair, visitors proceeded upward to a large space, on a level slightly above that of the exterior ground and directly over the Clam Room. Here, visitors entered a spherical mirrored dome, an "other-worldly creation", which "mesmerized, delighted, terrified, intrigued, baffled, entranced and bewildered" (Packer n.d.). This journey in, down, and then up (similar to that in the Tower of the Sun) caused disorientation and was unsettling.

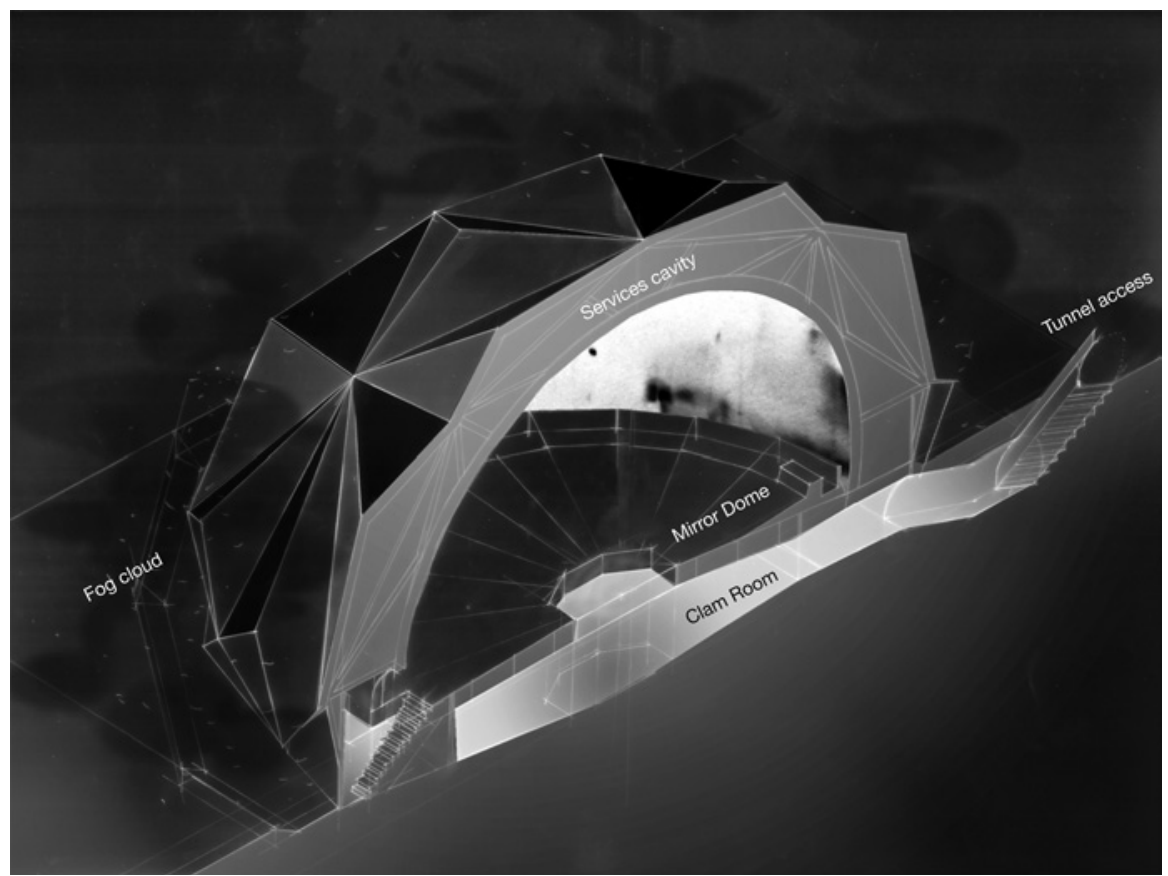

John Pearce, the project architect, recounts that his role was to meld the discontinuous elements of the Pavilion, allowing the flow of visitors to move from one space to the next without obstruction (1972: 246). Defending the Clam Room from efforts to trim the budget, Pearce recognised its importance as a dim antechamber that would radically differentiate the interior from the exterior while maintaining this continuity. The disjunction between interior and exterior was also accentuated by the pavilion's construction. Whereas the exterior was hard and crystalline reinforced fibreglass, the mirror dome within it was rounded and soft. The dome's inner surface was balloon-like, fabricated in Melinex, an aluminised Mylar, and kept aloft by pneumatics. An access and services void isolated the airtight interior dome from the crystalline exterior. There was no obvious volumetric relation between the two parts of the building: while the interior dome is recorded as 27.5 metres in diameter, the exterior breadth was over 35 metres.

Though intended to host choreographed performances, the unchoreographed performance of visitors became the design's focus and most remarkable feature. As 


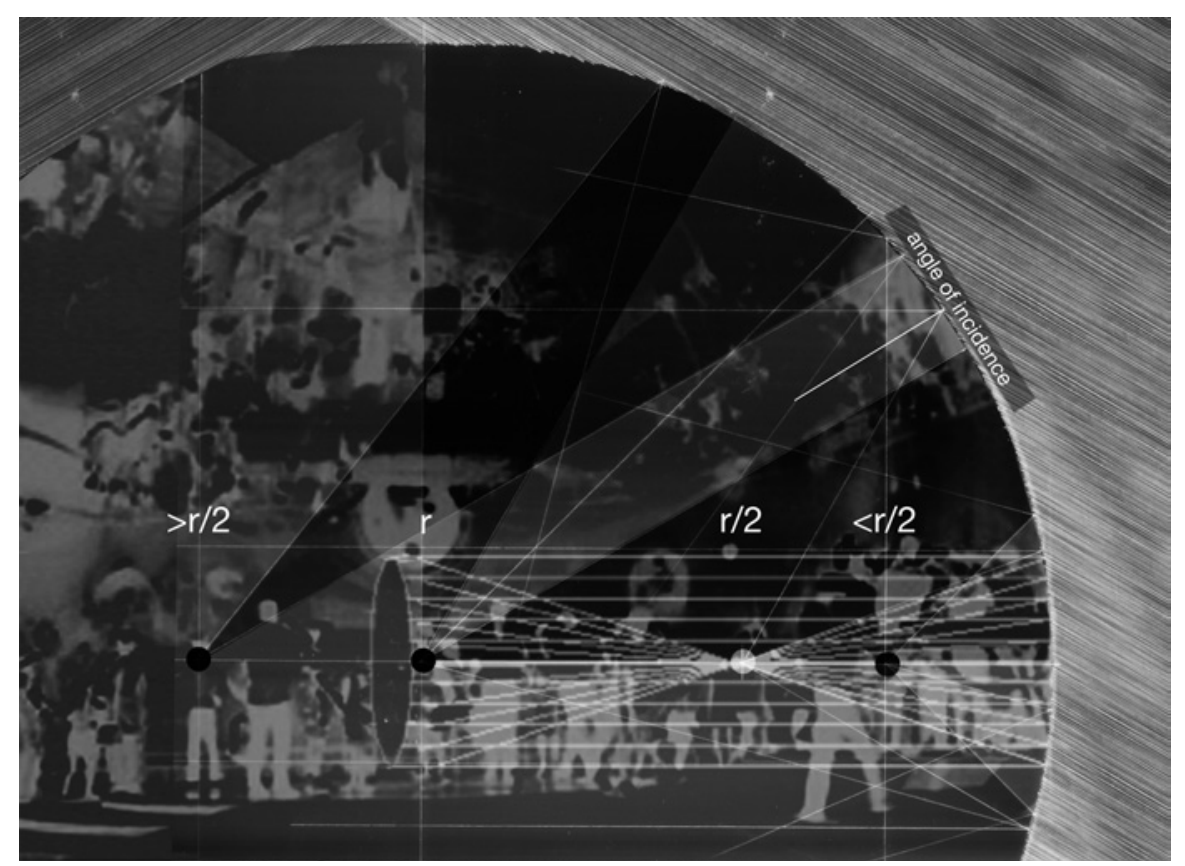

Section diagram showing the "egocentric viewpoint" at $r$ (the radius).

the narrator suggests in the opening scenes of Eric Saarinen's 1970 documentary The Great Big Mirror Dome Project:

All of us have had the experience of standing in front of a mirror and seeing ourselves as others see us but how many of use have stood inside a mirror and seen the world all around us as a reflection of ourselves?

In the documentary, Robert Whitman, who had first suggested the mirrored interior (Klüver 1971: 2759, n.2), explained his ideas for the space as an open environment in which people were to be free to do what they wanted;

... and you want them to understand that, and want them to accept that responsibility, you want them to be able to look at what they want to look at, see what you want to see, ... to escalate [their] mental involvement into a real one, in the real world. It's a philosophical machine that I think everybody knows, works. (Saarinen 1970)

What did visitors see in this "philosophical machine"? Armed with listening devices and a light-switching mechanism to play with, visitors found no object to see on arrival, and no performance beyond their own responses. All that remains of their experience today are the descriptions of the Pavilion's designers (Joseph 2006: 91, n16). According to Klüver (1971), the dome's spherical mirror returned the visitors to themselves as multiple, weird and composite images, composed of "virtual" and "real" reflections. Concept and experience relied heavily on these optical phenomena: a "virtual image" (e.g., a reflection in a flat mirror) shows the object reversed, left-to-right, but the right way up. Appearing behind the surface of the mirror, the reflection gets smaller as the viewer moves away from the mirror surface, and recedes into the distance. "Real images" (e.g., reflections on the concave side of a spoon) are reflected in front of a reflective surface, and the reflected object appears to hang in space like a hologram. Seen upside-down, the reflections grow as the viewer moves away from the mirror, reaching a maximum size as the viewer reaches the radius, or centre, of the sphere. 
The light rays reflected as "real images" have a focal depth relative to the radius of the curve. Elsa Garmire (1972: 204), the project's optical engineer, described the focal point at the centre of the mirror dome as "the egocentric viewpoint". Visitors standing at this focal point of the dome would see their reflected image dispersed over the entire dome surface. While this must have been a strange experience, according to Klüver the more unnerving effects were "second order" reflections, which occurred when virtual and real images were reflected more than once, producing real-virtual images, real-real images or virtual-real images.

Whitman was particularly fascinated by the possibilities offered by "real images", which he described as ghost-like (Joseph 2006). Their proliferation in the dome suggests an analogy between his "machine" and a "funny experiment" described by Jacques Lacan in 1953 (Le Gaufney 2005: 276-7). Elaborating on the mirror phase, Lacan pinpointed a moment of alienation, when a child becomes aware of itself as an image/reflection detached from its own inner thoughts and feelings. Bruce Fink (1997: 45-6) explains that this moment constitutes the child's subjectivity as a split between consciousness and appearance. When the child looks to the mother for assurance that she, too, recognises the reflective schism, she may not receive this confirmation. Thus, the interiority of thought is revealed as distinct from the exteriority of appearances. ${ }^{4}$ Lacan's "funny experiment" with curved mirrors is described as a complicated arrangement through which an illusion of unity or harmony was to be generated, subverting the mirror stage. An inverted vase, located beyond the focal distance of a concave mirror, could be used to create a "real image", floating in space, of a vase. Meanwhile, flowers, held the right way up and located within the focal distance, might reflect a "virtual image", so that the flowers appear to set inside the vase (Holm 2000: 55-56).

Lorens Holm proposes that Lacan's "device ... would be a fantastic model for an architecture (in league with the camera obscura and Plato's cave, or Laugier's primitive hut, or Absalon's [Cells])” (2000: 56). ${ }^{5}$ Perhaps the Mirror Dome was just such an architectural fantasy. Klüver also described the compound reflections in the Mirror Dome in a manner which recalls Lacan's "funny experiment”. He described instances when dome visitors could converse face to (reflected) face with people who were standing at a distance behind them, reminiscent of the rhyme "backto-back they faced each other". The non-linear reflective architecture generated dramatically different perspectives, even for those standing close together (Klüver 1972: 247-254), such that no two visitors could ever predict how, or where, an image effect would appear. This emphasised individualised experiences of perception at the expense of processes of collective recognition.

4 Lacan argued that language sets in train a similar process of alienation, where what can be said is necessarily different from what may be thought, and where verification of understanding is sought through speech. Like the child, who lacks the unity of image and thought that the mother exhibits, users of language forever desire unity and commonality between expression and interpretation.

5 Holm, however went on to state, "it can only be understood metaphorically - or at most analogically - when applied to the subject of perception".

\section{Conclusion}

A comparison of these two experimental spaces at Osaka's 1970 Expo shows that they used similar techniques of enclosure to produce radically different attitudes to interiority. Both sought to internalise the Expo theme "Progress and Harmony" by presenting visitors as the subjects and performers of the theme. Ecce homo, see yourself, and what you can become! Okamoto's Tower of the Sun disclosed a Jomônal space of "primal vitality", via a symbolic, Surrealist language that can provide new critical readings even today. By contrast, the Pepsi Pavilion experiment, for all its interior surface appearance of mesmerism and delight, seems to have failed in effecting permanent change in the visitors' sensibilities. Like the designers of the Osaka Expo '70 infrastructure, E.A.T. set out to supersede traditional symbolisms and to address instead the opticality of communication itself. By turning their focus away from the messiness of traditional interpretation, they 
hoped to create a frame for meaning out of experimental optics. However the hermetic interiority of the Pepsi Pavilion could only produce feedback loops without end: the potential narcissism of seeing one's self reflected everywhere while, everywhere else, the struggle to differentiate real from reflected, and self from object, must have pushed visitors toward the legendary psychasthenia of Roger Callois (2003: 100-3).

\section{References}

Callois, R. (2003). Mimicry and Legendary Psychasthenia. In C. Frank (Ed.), The Edge of Surrealism: a Roger Callois Reader (pp. 89-103). Durham and London: Duke University Press. Fink, B. (1995). The Lacanian subject: between language and jouissance. Princeton, N.J.: Princeton University Press.

Garmire, E. (1972). An Overview. In B. Klüver (Ed.), Pavilion by experiments in art and technology (pp. 173-206). New York: Dutton.

Le Gaufey, G. (2005). Looking at the mirror image; the stare and the glance. In H. Preester (Ed.), Body image and body schema: interdisciplinary perspectives on the body (pp. 273-282). Amsterdam \& Philadelphia: J. Benjamins Publishing Co.

Holm, L. (2000). What Lacan said re: architecture. Critical Quarterly, 42(2), 29-64.

Isozaki, A. (2006). Japan-ness in architecture. MIT Press.

Joseph, B. W. (2006). Plastic Empathy: The Ghost of Robert Whitman. Grey Room, 64-91.

Klüver, J. (1971). Photographic Recording of Some Optical Effects in a 27.5-m Spherical Mirror. Applied optics, 10(12), 2754-9.

Lacan, J. (1988). The seminar of Jacques Lacan: book 1 (1st ed.). New York: Norton.

Lockyer, A. (2007). The Logic of Spectacle c. 1970. Art History, 30(4), 571-589.

Media Art Net. (2011, February 21). Media Art Net I E.A.T. - Experiments in Art and Technology: Pepsi Pavilion for the Expo '70. Retrieved February 21, 2011, from http://www.medienkunstnetz. de/works/pepsi-pavillon/

Packer, R. (2004). The Pavilion: Into the 21st Century: A Space for Reflection. Organised Sound, 9(03), 251-259.

Packer, R. (n.d.). Tribute to Billy Kluver. Retrieved February 21, 2011, from http://www.zakros.com/ projects/pavilion/billy.html

Pearce, J. (1972). An Architect's View. In B. Klüver (Ed.), Pavilion by experiments in art and technology (pp. 255-265). New York: Dutton.

Rose, B. (1972). Art as Experience. In B. Klüver (Ed.), Pavilion by experiments in art and technology (pp. 60-105). New York: Dutton.

Saarinen, E. (1970). The Great Big Mirror Dome Project. Experiments in Art and Technology Los Angeles records, 1969-1979. The J. Paul Getty Trust.

Taro Okamoto Museum of ART. (n.d.). 100 Years Old, Admirable TARO -TARO's Mask; April 7 July 3, 2011. Retrieved March 31, 2011, from http://www.taromuseum.jp/english/index_english.html Tarô, O. (2009). On Jomon Ceramics. Art In Translation, 1, 49-60.

Tomkins, C. (1972). Outside Art. In B. Klüver (Ed.), Pavilion by experiments in art and technology (pp. 105-165). New York: Dutton.

Urushima, A. Y. F. (2007). Genesis and culmination of Uzo Nishiyama's proposal of a "model core of a future city" for the Expo 70 site (1960-73). Planning Perspectives, 22, 391-416.

Vidler, A. (2002). Warped Space: Art, Architecture, and Anxiety in Modern Culture. Cambridge, Mass.: MIT Press.

Wesemael, P. van. (2001). Architecture of instruction and delight: a socio-historical analysis of world exhibitions as a didactic phenomenon (1798-1851-1970). Rotterdam: 010 Publishers.

Worringer, W. (1953). Abstraction and Empathy: A Contribution to the Psychology of Style. London: Routledge and Kegan Paul. 